\title{
水素チャージした Fe-Ni合金の内部摩擦
}

\begin{abstract}
関
博 司* 浅 野

滋**

J.Japan Inst.Metals, Vol.48, No.7(1984), pp.694-699

Internal Friction in Hydrogen-Charged Fe-Ni Alloys

Hiroshi Seki* and Shigeru Asano**

Internal friction was measured at about $500 \mathrm{~Hz}$ from $160 \mathrm{~K}$ to $370 \mathrm{~K}$ in $F C C$ Fe-Ni alloys subjected to electrolytic hydrogen charging. A relaxation peak of internal friction caused by hydrogen was found at $260 \mathrm{~K}$ in an $\mathrm{Fe}-54.0 \% \mathrm{Ni}$ alloy and at $240 \mathrm{~K}$ in an $\mathrm{Fe}-72.8 \% \mathrm{Ni}$ alloy, together with two small sub-peaks around $225 \mathrm{~K}$ and $265 \mathrm{~K}$. The main hydrogen peak was always larger in the Fe$54.0 \% \mathrm{Ni}$ alloy than in the $\mathrm{Fe}-72.8 \% \mathrm{Ni}$ alloy. Their heights increased with the current density of electrolytic hydrogen charging and decreased with the hydrogen outgassing during repeated measurements. The activation energy of the hydrogen peak was estimated by the peak-shift method to be $E=43.2 \mathrm{~kJ} / \mathrm{mol}$ in the $\mathrm{Fe}-54.0 \% \mathrm{Ni}$ alloy and $E=42.3 \mathrm{~kJ} / \mathrm{mol}$ in the $\mathrm{Fe}-72.8 \% \mathrm{Ni}$ alloy. These values of the activation energy are comparable to recent data on hydrogen diffusion in the corresponding $\mathrm{Fe}-\mathrm{Ni}$ alloys. Plastic deformation did not change the height and the shape of the hydrogen peak but affected considerably the higher-temperature sub-peak. Therefore, the hydrogen peak is independent of the presence of dislocations and might be a Snoek-type relaxation of dissolved hydrogen atoms, presumably being caused by the stress-induced ordering of hydrogen atom-pairs or clusters in the FCC lattice of $\mathrm{Fe}-\mathrm{Ni}$ alloys. On the other hand, the higher-temperature sub-peak is a kind of the hydrogen cold work peak and might be caused by dislocation motion with hydrogen atmosphere.
\end{abstract}

(Received March 29, 1984)

Keywords : internal friction, hydrogen, iron-nickel alloys, Snoek peak, hydrogen diffusion, plastic deformation

\section{I. ま え がき}

金属中の水素は，侵入型不純物原子としては最小の格子 欠陥である。一般に格子欠陥は金属材料の諸性質を著しく 変化させるが, 水素の場合は水素脆性の現象が知られてい る，格子欠陥の挙動を調べるための手法はさまざまであ り，そのらちのひとつに内部摩擦法がある。内部摩擦の研 究によって今までに金属中の水素に関して有益な情報が少 なからずもたらされてきた。

金属中に侵入型不純物原子が存在することによって内部 摩擦ピークが観測されることがある。 $B C C$ 金属の場合は 一般に，侵入型不純物原子が異方性固溶歪をもつため， ス ネークピークと呼ばれる内部摩擦ピークが観測される。乙 かし今のところ，水素に関してはスネークピークが確認さ れていない，それに対し FCC 金属の場合には，侵入型不 純物原子が単独に存在しても固溶丕は等方性であるため, $B C C$ 金属のようなスネークピークは期待されない. しかし 実際には，多くの FCC 金属で類似のスネーク型ピークが
報告されている(1)-(8). とくに水素に関しても例外ではな く,オーステナイト系ステンレス鋼に执いてスネーク型緩 和ピークが観測されている(9)-(11).

$$
\text { オーステナイト系ステンレス鋼の場合の内部摩擦ピーク }
$$

は，固溶水素によるスネーク型緩和現象として特徵づけら れ，水素原子対の応力誘起配向運動に起因するものではな いかと考兄られている(10)-(12)。この内部摩擦ピークに関 しては, 塑性変形によって導入される格子欠陥の影響を受 けないとされている(12)(13). 一方，これと類似の現象が $F C C$ の $\mathrm{Fe}-\mathrm{Ni} 2$ 元合金に拈いても見出された(14)(15). この 場合の内部摩擦ピークも，オーステナイト系ステンレス鋼 の場合と同様にスネーク型緩和ピークとみなせるものであ るが(15), 詳細な特性や水素以外の格子欠陥の影響につい ては明らかにされていない。

そこで本研究では，Fe-54.0\% Ni 合金および $\mathrm{Fe}-72.8 \%$ $\mathrm{Ni}$ 合金に詨して，水素チャージを施して内部摩擦を測定 し，とくに水素濃度に詨する変化や時効挙動を詳細に調べ た。 また，水素以外の格子欠陥の影響を明らかにするため

* 名古屋工業大学大学院生 (Graduate Student, Nagoya Institute of Technology, Nagoya)

** 名古屋工業大学金属工学科 (Department of Metallurgical Engineering, Nagoya Institute of Technology, Nagoya) 
に，焼鈍材とともに塑性変形材についても同様の測定を行 なって，水素による内部摩擦ピークに括ける転位の役割を 検討した。

\section{II. 実 験 方 法}

実験に用いた材料は, 純度 $99.9 \%$ の電解鉄と純度 99.95 $\%$ の電解ニッケルを真空溶解して作製した 2 種類の $\mathrm{Fe}-\mathrm{Ni}$ 2 元合金であり，その組成は Fe-54.0\% Ni 合金 (52.8 at\% $\mathrm{Ni}$ 牤よび $\mathrm{Fe}-72.8 \% \mathrm{Ni}$ 合金 $(71.8 \mathrm{at} \% \mathrm{Ni}$ ) である。試料 は $80 \mathrm{~mm} \times 10 \mathrm{~mm} \times 1 \mathrm{~mm}$ に成形し，真空中 $1323 \mathrm{~K}$ で $1.8 \mathrm{ks}$ の溶体化処理を行なった後, 水水中へ急冷した。 こ のよらな試料作製条件のもとでは，マルテンサイト相や規 則格子相 $\left(\mathrm{FeNi}_{3}\right)$ の生成をさけることができ，試料はFCC 単相状態となる，表面酸化物をエメリ一研磨によって除去 し,さらに試料表面を約 $0.1 \mathrm{~mm}$ 以上化学研磨してから測 定に用いた。

試料への水素チャージは陰極電解法により行なった。電 解液としては $1.3 \mathrm{~mol} / \mathrm{m}^{3}$ の $\mathrm{As}_{2} \mathrm{O}_{3}$ を含む $500 \mathrm{~mol} / \mathrm{m}^{3}$ の 硫酸水溶液を用い，試料をカソード，白金電極をアノード として, 液温約 $290 \mathrm{~K}$, 電解時間 $72 \mathrm{ks}$ で定電流電解を行 なった。電流密度は $500 \mathrm{~A} / \mathrm{m}^{2}$ を標準としたが，固溶水素 濃度の影響を調べるために $5 \mathrm{~A} / \mathrm{m}^{2}, 50 \mathrm{~A} / \mathrm{m}^{2}$ の条件でも 測定を行なった。

このような水素チャージ条件のもとでは, 試料内部まで 固溶水素が均一に分布するにはいたらず，試料表面層にの み高濃度の水素が存在する状態となっている(9)(10). その ため，大きな電流密度の場合には，試料表面層に水素化物 が形成されることがある。乙かし，このような水素化物 は，純ニッケルにくらべて Fe-Ni 合金ではきわめて不安 定であって，水素チャージの終了後には速やかに分解して しまら (16)。乙たがって, 室温以上にわたる内部摩擦測定 に拈いて時効挙動を追跡することにより，水素化物の効果 を消去することは可能である。な拉，本研究に打いても小 さな電流密度の場合 $\left(5 \mathrm{~A} / \mathrm{m}^{2}\right)$ には，X線回折で観測するか ぎりは水素化物の形成が認められなかった，試料表面層に 打ける水素濃度は本研究では実測されていないが，佐賀と 宮田 ${ }^{(16)}$ の水銀置換法の結果によれば，室温に和ける拡散 性水素の濃度は電流密度 $500 \mathrm{~A} / \mathrm{m}^{2}$ の場 合は 30 at $\%$ 程度 と考えられる。

また，塑性変形の影響を調べるために，水素チャージ前 に引張歪を与えた試料についても測定を行なった。この場 合は長さ約 $110 \mathrm{~mm}$ の試料を引張試験機によって約 $9 \%$ の 引張変形をした後, 両端を切断して一様変形部分の $80 \mathrm{~mm}$ を測定に用いた。

内部摩擦の測定は約 $500 \mathrm{~Hz}$ の自由端横振動で自由減衰 法により行なった。水素チャージ後の試料を室温で約 20 分以内に装置へ取りつけ, 真空排気して冷却した後に, 昇 温速度 $0.017 \mathrm{~K} / \mathrm{s}$ により $160 \mathrm{~K} \sim 370 \mathrm{~K}$ の温度範囲で測定 を行なった。 また，活性化パラメーターを評価するため
に，試料の寸法を調整して $200 \mathrm{~Hz} \sim 1500 \mathrm{~Hz}$ の範囲で振 動数を変化させた。な怔，内部摩擦は試料の最大麥振幅を 約 $2 \times 10^{-7}$ として無磁場中で測定したものである.

\section{III. 実 験 結 果}

\section{Fe-54.0\%Ni 合金の場合}

まずはじめに水素濃度依存性をみるために，電流密度 を大幅に変化させて水素チャージした場合の測定結果を Fig.1 に示す．水素チャージ前には内部摩擦ピークはまっ たくみられなかったが，水素チャージ後には約 $500 \mathrm{~Hz}$ の 振動数で,つねに注 $260 \mathrm{~K}$ の温度位置に 1 個の内部摩擦 ピークが観測された。この図から明らかなように，この内 部摩擦ピークの高さは電流密度に強く依存しており，水素 濃度とともに増加することがわかった。ピークの位置は電 流密度によらずほぼ一定とみなせるが，電流密度が極めて 低い場合にはやや高温側にずれるようであった。なお，以 下に执いてはいずれの測定結果も，電流密度 $500 \mathrm{~A} / \mathrm{m}^{2}$, チャージ時間 $72 \mathrm{ks}$ の条件で水素チャージを施したもので ある。

$\mathrm{Fe}-\mathrm{Ni}$ 合金中の水素は, 室温以上の温度領域では時間経 過にともなって試料の外へ散逸していく(16). そこで, 370 K までの昇温測定の過程をくり返すことによって，この内 部摩擦ピークの時効挙動を調べた結果を Fig.2 に示す. 1 回目の測定結果は前図の $500 \mathrm{~A} / \mathrm{m}^{2}$ のピークと同じもの であるが，2 回目の測定ではピーク高さが約 $1 / 2$ まで急速に 減衰し，それ以後は極めてゆるやかに減衰した。な和，以 下の測定結果はすべて，3回目と 4 回目の測定の間で約 1 週間の室温時効を行なったものである。ピーク位置につい ては, 水素チャージ直後は約 $260 \mathrm{~K}$ の温度であったが， 2 回目の測定ではやや高温側にずれて約 $265 \mathrm{~K}$ の温度とな り，それ以後は 4 回目の測定までほぼ $265 \mathrm{~K}$ のまま不変 だった。このような時効挙動から考えると, 水素チャージ 後にみられる内部摩擦ピークは，急速に減衰する主ピーク $(260 \mathrm{~K})$ と時効後も残存する副ピーク $(265 \mathrm{~K})$ とから構成さ れているようである。また $225 \mathrm{~K}$ 付近にも，遅い減衰過程

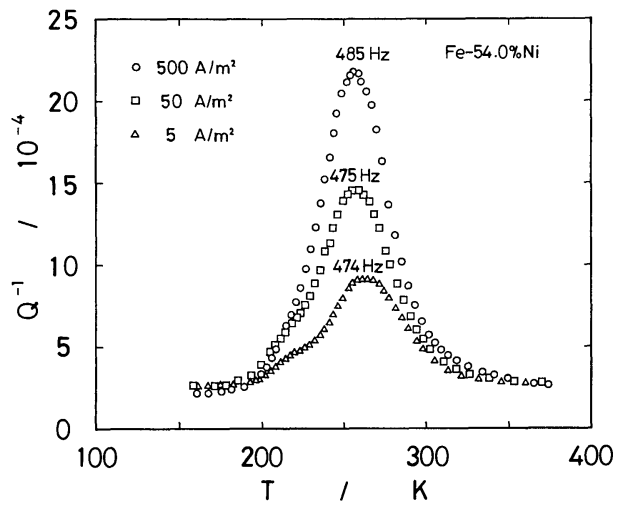

Fig.1 Current density dependence of the hydrogeninduced internal friction peak in the hydrogencharged $\mathrm{Fe}-54.0 \% \mathrm{Ni}$ alloy. 


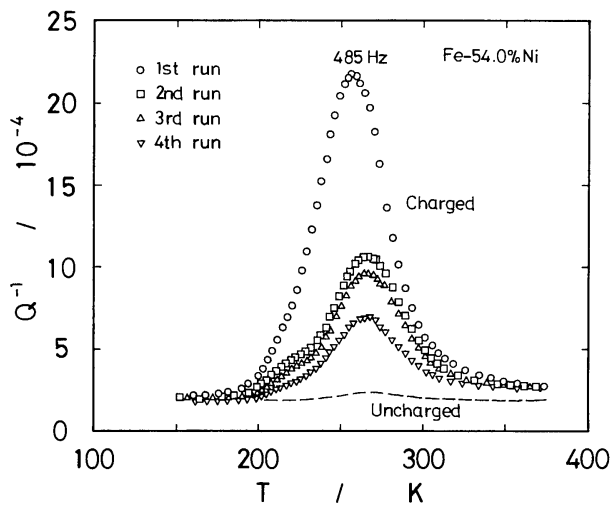

Fig.2 Repeated measurements of internal friction in the annealed $\mathrm{Fe}-54.0 \% \mathrm{Ni}$ alloy charged with hydrogen at $500 \mathrm{~A} / \mathrm{m}^{2}$ for $72 \mathrm{ks}$.

を示す小さな副ピークがみられる。 $370 \mathrm{~K}$ までの測定中に 急速に減衰するのは主ピークの方である。これは固溶水素 の拡散散逸過程に対応するものと考光られる。そこで以下 そ执いては，固溶水素に直接的に関係づケられる主ピーク を水素ピークと呼ぶことにする，固溶水素濃度が高い場合 には，2 個の副ピークは水素ピークに拈拈い隠されてしま う。この観点から Fig.1 の電流密度依存性をみると, 内部 摩擦ピークが $5 \mathrm{~A} / \mathrm{m}^{2}$ のときにやや高温側にずれていたの は，固溶水素濃度が低くて水素ピークが十分に発達してい なかったために， $265 \mathrm{~K}$ 付近の副ピークが姿を現わしてい たものと考光られ，同時に $225 \mathrm{~K}$ 付近の副ピークもわずか に形跡を示している。

そこで，これらの内部摩擦ピークと他の格子欠陥との関 係を調べるために，塑性変形材に水素チャージを施して測 定を行なった，Fig.3 は，約 $9 \%$ の引張歪を与光た場合と その後に水素チャージを施した場合の測定結果である．塑 性変形のみの状態では加工ピークのようなものは明膫には みられなかった，水素チャージを施すことによって内部摩 擦ピークが現われたが，ピークの位置扣よび高さは焼鈍状 態(Fig.2)の水素ピークとほぼ同じであった。 また，くり 返し測定中の時効挙動もほぼ同様であって，2回目の測定 までは急速に減衰し，それ以後は極めてゆるやかに減衰す るものであった。つまり水素ピークに関するかぎり塑性変 形の影響はほとんど受けないるのと考学られる。しかしな がら，水素ピークより高温側に打いては内部摩擦が焼鈍状 態にくらべやや高くこれは高温側の副ピークが塑性変形 の影響を受けたことを示している。

次に，水素ピークの活性化パラメーターを評価し，実測 されるピークの形状を検討した，Fig.4 は，いわゆるアレ ニウスプロットであって, 試料の共振振動数 $f$ の変化にと もならピーク温度 $T_{\mathrm{p}}$ の変化を調べたものである，図にみ るように，測定值 (図中の○印) は直線上に並び，このピー クがアレニウスの関係式 $f=f_{0} \exp \left(-E / R T_{\mathrm{p}}\right)$ で記述され る緩和型内部摩擦であることがわかった。活性化パラメー

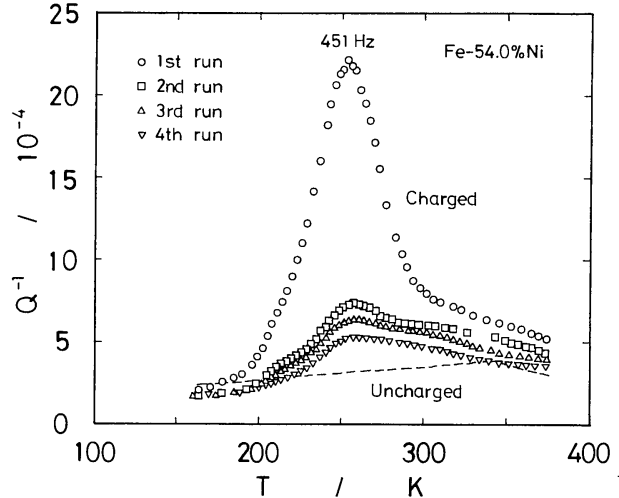

Fig.3 Repeated measurements of internal friction in the deformed $\mathrm{Fe}-54.0 \% \mathrm{Ni}$ alloy charged with hydrogen at $500 \mathrm{~A} / \mathrm{m}^{2}$ for $72 \mathrm{ks}$.

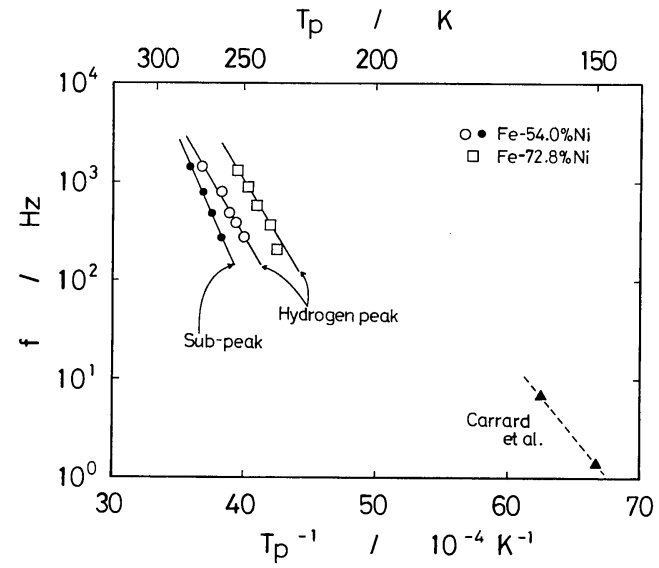

Fig.4 Arrhenius plot of the peak temperature against the vibrational frequency.

ターとして，活性化エネルギー $E$ 打よび振動数因子 $f_{0}$ を 求めたところ

$E=43.2 \mathrm{~kJ} / \mathrm{mol}, \quad f_{0}=3.0 \times 10^{11} \mathrm{~s}^{-1}$ という值を得た。また，この緩和ピークを単緩和理論曲線 (Debye curve) と比較したところ，やや広がった形状をし て括り，緩和時間の対数規格分布に括ける広がりのパラメ ーター ${ }^{(17)}$ は $\beta=1 \sim 2$ であって，ピークの広がりは高温側 よりも低温側の方がいくらか大きかった。また参考のため に，高温側の副ピークについてのアレニウスプロットも Fig.4 (図中の・印) に示されている。この場合の活性化パ ラメーターとしては $E=57.0 \mathrm{~kJ} / \mathrm{mol}, f_{0}=7.3 \times 10^{13} \mathrm{~s}^{-1}$ と いら值が得られた。

\section{2. $\mathrm{Fe}-72.8 \% \mathrm{Ni}$ 合金の場合}

Fig.5 は，焼鈍状態の試料抢よびそれに水素チャージを 施した場合の測定結果である。水素チャージ条件は $\mathrm{Fe}$ $54.0 \% \mathrm{Ni}$ 合金の場合と同一であって，電流密度は $500 \mathrm{~A} /$ $\mathrm{m}^{2}$ ，チャージ時間は $72 \mathrm{ks}$ とした．水素チャージ前には内 部摩擦にピークはみられなかったが，水素チャージ後には 約 $240 \mathrm{~K}$ の温度に内部摩擦ピークが観測された。図からわ かるように，この場合の水素ピークは $\mathrm{Fe}-54.0 \% \mathrm{Ni}$ 合金 


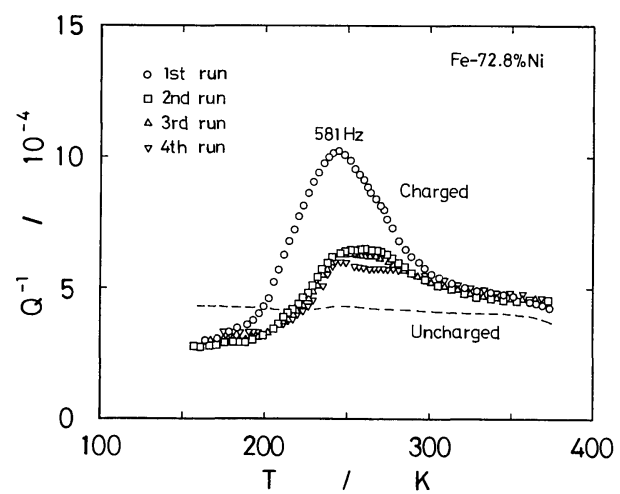

Fig.5 Repeated measurements of internal friction in the annealed $\mathrm{Fe}-72.8 \% \mathrm{Ni}$ alloy charged with hydrogen at $500 \mathrm{~A} / \mathrm{m}^{2}$ for $72 \mathrm{ks}$.

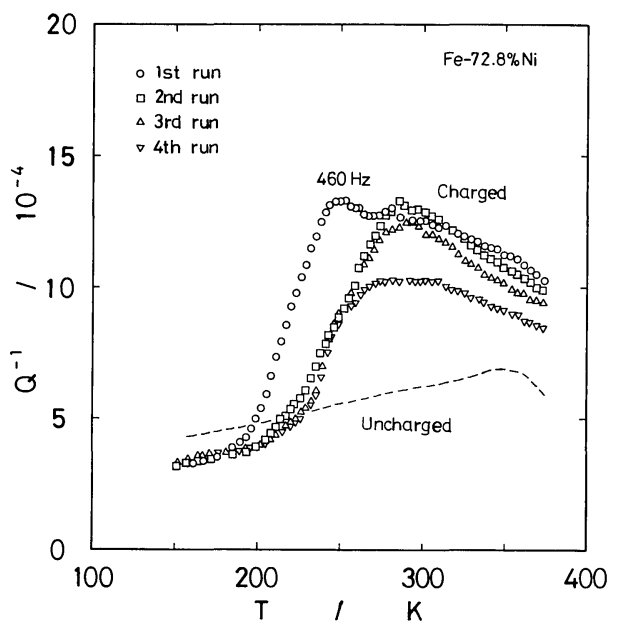

Fig.6 Repeated measurements of internal friction in the deformed $\mathrm{Fe}-72.8 \% \mathrm{Ni}$ alloy charged with hydrogen at $500 \mathrm{~A} / \mathrm{m}^{2}$ for $72 \mathrm{ks}$.

の場合にくらべてやや低温側位置して特り，その高さは 小さかった．水素ピークはくり返し湘定による時効過程で 減衰し，やはり高温側の副ピークが姿を現わしたが，その 位置は $\mathrm{Fe}-54.0 \% \mathrm{Ni}$ 合金の場合汪ど明膫ではなかった。

Fig.6 は，塑性変形の影響を調べるために約 $9 \%$ の引張 変形を施した試料に水素チャージしたものである. 水素チ ヤージ直後には $\mathrm{Fe}-54.0 \% \mathrm{Ni}$ 合金の場合とは異なって， 水素ピークと副ピークとが分裂して観測された。この場 合，水素ピークが見かけ上 $10 \mathrm{~K}$ 棌ど高温 側飞観測された のは，副ピークが相対的に大きなためであり，副ピークの 成分を差し引けば焼鈍状態と同じく $240 \mathrm{~K}$ 付近に位置する ことがわかった。 くり返し測定による時効過程で水素ピー クは急速に減衰したが，副ピークはゆるやかに減衰してい った。したがって，水素ピークはやはり塑性変形の影響を あまり受けないものと判断できるが，高温側の副ピークは 塑性变形により大きく変化した。この事実から，高温側の 副ピークは水素だけでなく，転位の寄与も含むものと考兄 られる。

振動数の変化にともならピーク温度の変化を調べた結
果，Fig.4 (図中の $\square$ 印) に示されているように，Fe-72.8\% $\mathrm{Ni}$ 合金についても水素ピークはアレニウスの関係式が成 りたつものであった。活性化パラメーターとしては

$$
E=42.3 \mathrm{~kJ} / \mathrm{mol}, \quad f_{0}=6.9 \times 10^{11} \mathrm{~s}^{-1}
$$

が得られた。この場合も単緩和理論曲線よりやや広がって 拉り, $\beta$ 值はほぼ 3 であった。

\section{IV. 考察}

水素を吸収した $\mathrm{Fe}-\mathrm{Ni}$ 合金についての内部摩擦を用い た研究は今のところ少ないようである。Carrard らは水 素吸収した $\mathrm{Fe}-24.2 \% \mathrm{Ni}-0.41 \% \mathrm{C}$ 合金の内部摩擦を叔じ り振子法によって測定し，150 K に水素による内部摩擦ピ 一クを見出した。 Carrard らによれば，この内部摩擦ピー クは $B C C$ マルテンサイト中での水素と転位の相互作用に よるものとされている(18)。また，Tanaka らは Ni-H 系 合金の内部摩擦を測定した。 Tanaka らによれば，塑性変 形した場合にのみ水素による内部摩擦ピークが観測され， この場合の内部摩擦ピークは水素と転位の相互作用による 冷間加工ピークとされている(19).

それに対して以前に報告したように，われわれは水素吸 収した FCC の $\mathrm{Fe}-\mathrm{Ni}$ 合金の内部摩擦を横振動法によっ て測定し，水素に起因する内部摩擦ピークを $240 \mathrm{~K} \sim 260 \mathrm{~K}$ の温度領域に見出した ${ }^{(14)(15)}$. 本研究の結果によれば, こ の内部摩擦ピークは現象的には次のような特徵を有するこ とがわかった。

（1）振動数が一定であるかぎりはつねにほぼ一定の温度 に水素ピークが現われ，水素濃度とピーク高さは密接な関 係汇ある。

（2）水素ピークは典型的な緩和ピークであるが，高ニッ ケル組成の合金の方が低温側飞現われ，その高さが小さ い.

（3）水素ピークは，焼鈍状態であろうと塑性变形状態で あろらとほぼ同一温度に現われ，塑性変形の影響をあまり 受けない。

（4）副ピークは塑性変形の影響を受け，時効による減衰 が著しく遅い。

われわれの知るかぎりでは，本研究の水素ピークおよび副 ピークは $\mathrm{Fe}-\mathrm{Ni}-\mathrm{H}$ 系合金に打いて今までに報告されてい なかった種類の内部摩擦ピークである. Fig.4 とは, 本研 究の結果とともに Carrard らの見出した内部摩擦ピーク も示されている. Carrard らの内部摩擦ピークは, 本研究 で用いた横振動法では $200 \mathrm{~K}$ 付近に 観測されるはずであ るが，本研究ではそれに対応する内部摩擦ピークは観測さ れなかった。 したがって，本研究の水素ピークは Carrard らとは異なった新しい緩和現象をとら光たものと考光られ る。

そこで，水素ピークの成因について考㝋てみことにす る. 本研究では水素チャージは陰極電解法を用いている が，固溶水素の効果をとら兄るために，できるかぎり表面 
損傷の生成されない条件を設定した。Fig.3,Fig.6 に示し たよらに，水素ピークは塑性変形の影響はあまり受けない ので，転位とは直接的に関係つけられるものではなく，固 溶水素のみに起因するものと考えられる．Fig.1 は，水素 ピークの緩和強度が固溶水素濃度と直接的に関係つけりられ ることを示している。

一方，前報(15)で検討したように，水素ピークが固溶水 素のみに起因することは水素拡散のデータと対比すること によっても明らかになる。 Fe-Ni 系合金については，マル テンサイト変態や規則格子形成の可能性があって，信頼性 の高い水素拡散のデータを得ることが困難とされてい る(20). ところが最近になって, Yamanishi ら ${ }^{(21)}$ は Fe$48.6 \% \mathrm{Ni}$ 合金に対する水素拡散のデータとして $E_{\mathrm{D}}=36.4$ $\mathrm{kJ} / \mathrm{mol}, D_{0}=37.6 \times 10^{-8} \mathrm{~m}^{2} / \mathrm{s}$ を報告している $\left(E_{\mathrm{D}}\right.$ は水素 拡散の活性化エネルギ一，D的 は水素拡散の前指数因子). それに対し，Fe-54.0\% Ni 合金に和ける水素ピークの活性 化エネルギーは $43.2 \mathrm{~kJ} / \mathrm{mol}$ であって，水素拡散の活性化 エネルギーにかなり近いものである。このことは，本研究 の水素ピークが固溶水素の拡散挙動をとらえたものであ り，固溶水素によるスネーク型緩和に起因することを示唆 する.ささらに，水素ピークがスネーク型緩和ピークである と仮定すれば，水素ピークの $f_{0}$ 值は $D_{0}$ への換算が可能 となるが(11)，Fe-54.0\% Ni 合金和よび $\mathrm{Fe}-72.8 \% \mathrm{Ni}$ 合金 に対する換算值 $D_{0}$ は Yamanishi らの值とオーダー的に 一致をみるものであった ${ }^{(15)}$.

このように内部摩擦ピークが固溶水素の拡散挙動に起因 することは，オーステナイト系ステンレス鋼の場合(10)-(12) と同様である，オーステナイト系ステンレス鋼と本研究の $\mathrm{Fe}-\mathrm{Ni}$ 合金とは合金組成は大いに異なるが，構造はどちら も水素を固溶する $F C C$ 結晶である。一般に，FCC 結晶中 に侵入型不純物原子が単独に存在しても， $B C C$ 結晶の場 合とは違って固溶雨に異方性がないためスネーク効果は期 待できない。したがって，FCC 結晶でスネーク型緩和現 象があるとすれば，固溶原子の複合体にその原因を求めな ければならない(22)(23). 固溶原子の複合体の可能性として は，置換型原子と侵入型原子の複合体あるいは侵入型原子 同士の複合体の 2 種類が考えられる。このらち前者の可能 性は本研究の高濃度組成の $\mathrm{Fe}-\mathrm{Ni}$ 合金の場合は除外でき る、前にも述べたように，本研究の場合は特に表面層に約 30 at \% といら高濃度の水素が存在することから ${ }^{(16)}$, 後者 の可能性が考えられる，実際；本研究の横振動方式の測定 は，試料表面層の昰が最大となる条件であるため，特に表 面層の水素を敏感に検出することが可能である。乙たがっ て, 侵入型原子である水素原子同土の複合体の存在を仮定 することによって，本研究の水素ピークを解釈することは 合理的である，実測される水素ピークが単緩和理論曲線に くらべやや広がっていることから，水素原子同士の複合体 としては単純な 1 種類の原子対ではなく，原子対の距離ま
たは結合の強さに分布のある原子対か，めるいはクラスタ 一が考壳られる。

副ピークについては今のところ詳細はわからないが，時 効中の減衰の遅さから何らかの格子欠陥にトラップされた 水素が関与していると考学られる。特に高温側の副ピーク は，塑性変形によって転位密度が高くなるとピークの形状 が変化することから，転位の関与も考えられる，したがっ て,この副ピークは水素によって誘起された泠間加工ピー クの一種であろら。このような現象はオーステナイト系ス テンレス鋼の場合にもみられ(12)，今のところわれわれは 水素雲囲気をともなら転位の運動によるものと考えてい る。一方，低温側の副ピークについては，本研究の条件で は明確なデータが得られていないので，その機構の推測は 現状では不可能である。

\section{V. を と め}

$\mathrm{Fe}-54.0 \% \mathrm{Ni}$ 合金および $\mathrm{Fe}-72.8 \% \mathrm{Ni}$ 合金に対して, 約 $500 \mathrm{~Hz}$ の横振動法により内部摩擦の温度依存性を測定 したところ，固溶水素に起因した新しい緩和ピークが観測 された。 ピーク温度は，Fe-54.0\% Ni 合金では約 $260 \mathrm{~K} て ゙$ あり， $\mathrm{Fe}-72.8 \% \mathrm{Ni}$ 合金では約 $240 \mathrm{~K}$ であった。ピーク 高さは, 水素チャージの電流密度とともに増加し, 時効に よる水素散逸とともに減少した。この水素ピークは焼鈍状 態でも塑性変形状態でも現われ，塑性変形の影響をあまり 受けなかった、ピークシフト法により求めた活性化パラメ ーターは, Fe-54.0\% Ni 合金に対しては $E=43.2 \mathrm{~kJ} / \mathrm{mol}$, $f_{0}=3.0 \times 10^{11} \mathrm{~s}^{-1}$ であり，Fe-72.8\% $\mathrm{Ni}$ 合金に対しては $E=42.3 \mathrm{~kJ} / \mathrm{mol}, f_{0}=6.9 \times 10^{11} \mathrm{~s}^{-1}$ であった。 この活性化 パラメーターは水素の拡散データに対応するものであっ て, 水素ピークの機構が固溶水素の拡散過程と密接に関係 するものと考学らる。，したがって水素ピークは，水素の 原子対あるいはクラスターに起因したスネーク型緩和ピー クではないかと推測される。

また，小さな副ピークが $225 \mathrm{~K}$ 和よび $265 \mathrm{~K}$ 付近に観 測されたが，このらち高温側の副ピークは，水素䨌囲気を ともなら転位の運動による泠間加工ピークと考えられる。

\section{文献}

(1) T.S.Kê and C.T.Tsien : Scientia Sinica, 5 (1956) , 625.

(2) S.Diamond and C.Wert : Trans. Met.Soc.AIME, $239(1967), 705$

(3) J.M.Papazian and L.Himmel : J.Met., 16 (1964), 79 .

(4) R.R.Arons, J.Bouman, M.Wijzenbeek, P.T.A. Klaase, C.Tuyn, R.Leferink and G.De Vries : Acta Met., 15 (1967), 144.

(5) T.L.Wu and C.M. Wang : Scientia Sinica, 7 (1958), 1029 .

(6) M.G.Ulitchny and R.Gibala : Met. Trans., 4 (1973), 497.

(7) V.D.Verner : Phys.Met.Metall., 14 (1962), No.6, 70 .

(8) V.D.Verner : Soviet Phys. Solid State, 7 (1966), 1874. 
（9）浅野 滋, 後藤益弘, 大塚陸郎：日本金属学会誌, 39 (1975), 1318.

(10) 浅野 滋, 角田隆太郎, 大塚陸郎：日本金属学会 誌, 41 (1977), 338.

(11) S.Asano, M.Shibata and R.Tsunoda : Scripta Met., $14(1980), 377$.

(12) S.Asano and K.Oshima : Trans. JIM, 23 (1982), 530 .

(13) N.Igata, H.B.Chen and K.Miyahara : Scripta Met., $16(1982), 169$.

(14) 関 博司, 浅野 滋：名古屋工業大学学報, 34 (1982), 341 .

(15) S.Asano and H.Seki : Scripta Met., 18(1984), 117.

（16）佐賀二郎，宮田節男：日本金属学会誌，40(1976), 1098 .
(17) A.S.Nowick and B.S.Berry : Anelastic Relaxation in Crystalline Solids, Academic Press, (1972), 94.

(18) M.Carrard, C.Prioul, J.Plusquellec and P.Azou: J.de Phys., Supplément, 42 (1981), C5-187.

(19) K.Tanaka, H.Ryonai and M.Yamada : J.Appl. Phys., 52 (1981) , 3992.

(20) R.Dus and M.Smialowski : Acta Met., 15(1967), 1611.

(21) Y.Yamanishi, T.Tanabe and S.Imoto : Trans. JIM, 24 (1983) , 49.

(22) R.de Batist:Internal Friction of Structural Defects in Crystalline Solids, North-Holland Pub. Co., (1972), 162.

(23) A.S. Nowick and B.S.Berry : Anelastic Relaxation in Crystalline Solids, Academic Press, (1972), 284. 